\title{
Redesigning the Aspergillus nidulans xylanase regulatory pathway to enhance cellulase production with xylose as the carbon and inducer source
}

\author{
Patrick Ballmann ${ }^{1 \dagger}$, Jorge Lightfoot ${ }^{2 \dagger}$, Michael Müller $^{1}$, Stephan Dröge ${ }^{1}$ and Rolf Prade ${ }^{2^{*}}$ (i)
}

\begin{abstract}
Background: Biomass contains cellulose (C6-sugars), hemicellulose (C5-sugars) and lignin. Biomass ranks amongst the most abundant hydrocarbon resources on earth. However, biomass is recalcitrant to enzymatic digestion by cellulases. Physicochemical pretreatment methods make cellulose accessible but partially destroy hemicellulose, producing a C5-sugar-rich liquor. Typically, digestion of pretreated LCB is performed with commercial cellulase preparations, but C5-sugars could in principle be used for "on site" production of cellulases by genetically engineered microorganism, thereby reducing costs.
\end{abstract}

Results: Here we report a succession of genetic interventions in Aspergillus nidulans that redesign the natural regulatory circuitry of cellulase genes in such a way that recombinant strains use C5-sugar liquors (xylose) to grow a vegetative tissue and simultaneously accumulate large amounts of cellulases. Overexpression of XInR showed that under xylose-induction conditions only xylanase $C$ was produced. $X \ln R$ overexpression strains were constructed that use the $x y n C p$ promoter to drive the production of cellobiohydrolases, endoglucanases and $\beta$-glucosidase. All five cellulases accumulated at high levels when grown on xylose. Production of cellulases in the presence of pretreated-biomass C5-sugar liquors was investigated, and cellulases accumulated to much higher enzyme titers than those obtained for traditional fungal cell factories with cellulase-inducing substrates.

Conclusions: By replacing expensive substrates with a cheap by-product carbon source, the use of C5-sugar liquors directly derived from LCB pretreatment processes not only reduces enzyme production costs, but also lowers operational costs by eliminating the need for off-site enzyme production, purification, concentration, transport and dilution.

Keywords: Aspergillus nidulans, Biomass degradation, Biomass pretreatment, C5-sugar liquors, Cellulose hydrolysis, Cellulases, Cellobiohydrolases, Endoglucanases, Glucosidases, Enzyme production, Fungal cell factories, Xylose induced cellulase production, Xylanases, XynC, XInR

\footnotetext{
*Correspondence: rolf.prade@okstate.edu

†Patrick Ballmann and Jorge Lightfoot contributed equally to this work

2 Department of Microbiology \& Molecular Genetics, Oklahoma State

University, Stillwater, OK 74078, USA

Full list of author information is available at the end of the article
} 


\section{Background}

Lignocellulosic biomass (LCB) is the single most abundant renewable hydrocarbon resource on earth [1]. The runner-up hydrocarbon resource, which is non-renewable, is petroleum. Petroleum currently provisions the world market of starter chemicals for everything from low-cost, cents-per-gallon products (gasoline and diesel) all the way to high-end substrates such as the primers for plastics, polymers and fibers [2]. Two thirds of LCB is composed of hemicellulose (C5-sugars) and cellulose (C6-sugars), the hydrocarbon substrates for fermentation processes that produce low-cost high-volume as well as high-cost low-volume chemicals [3-5]. LCB enzymatic deconstruction mechanisms are widely dispersed across the tree of life: microorganisms, bacteria, fungi, algae, plants, and others have developed specialized sets of enzymes, such as hydrolases, oxidases and monooxygenases, all of which attack cellulose, hemicellulose and lignin [6]. The canonical enzyme set, namely cellobiohydrolase(s), endoglucanase(s) and $\beta$-glucosidase(s), completely deconstruct cellulose molecules to produce glucose as the final product [7]. However, enzymatic hydrolysis is hindered by the low accessibility (recalcitrance) of the crystalline structure of cellulose to enzymes [8-10].

To overcome this natural physical resistance of LCB to an enzyme-driven digestion process, several pretreatment technologies have been developed, focused in disrupting the intermolecular hydrogen bonds that make LCBs recalcitrant [11-13]. Pretreatments include mechanical (physical) methods, such as high-pressure homogenization [14], crushing, microwave [11], ultrasonic treatments [15] and vibrating ball mill grinding and compression techniques [16]. Chemical pretreatment technologies include Fenton oxidation chemistry-based treatments that focus on the production of hydrogen peroxide to break down recalcitrant glycoside and ligninbonds by oxidation [17], treatments with acids [18] or alkali [19], ionic liquids or extraction with organic solvents [12]. Often times, chemical and physical methods are combined $[11,20,21]$ and result in treatments such as steam explosion [20, 22], ammonia fiber expansion (AFEX) [23, 24], $\mathrm{CO}_{2}$ explosion [25] and $\mathrm{SO}_{2}$ explosion [26]. The bottom line on LCB pretreatments is that irrespective of the method, there is always partial decomposition of the hemicellulosic fraction, which contains an abundance of the C5-sugar xylose [4, 10,27].

For large-scale production of enzymes that break down LCBs, fungi have traditionally been used as cell factories to manufacture cellulases, xylanases and other auxiliary activities [28-32]. There have been considerable efforts to increase recombinant protein yields in Aspergilli by transcription factor engineering [33-35], reduction of extracellular protease activity [36, 37] and identification of strong promoters and protein secretion signals [38, 39]. Filamentous fungi such as Trichoderma and Aspergillus are able to use a broad range of sugars such as hexoses (C6-sugars) and pentoses (C5-sugars) as a carbon source to promote vegetative growth, however these carbon sources are insufficient to induce the synthesis of cellulases and other LCB degrading enzymes [40-42].

While fungi have been genetically engineered to secrete economically adequate yields of enzymes, the operational costs of synthesizing them continue to be excessive, largely because they demand an expensive carbon source to cultivate the vegetative tissue necessary to synthesize client proteins. Moreover, there exist the added costs of making them on distant sites, purification, concentration, conditioning and delivery to biomass processing sites [43-46].

Xylose found in pentosan-containing pretreated biomass liquors (PPTB), the byproducts of LCB pretreatments, is a cheap alternative carbon source that can be used as a substrate to manufacture enzymes. Using PPTBs as the raw material for the production of cellulases with fungal cell factories opens the prospect for low-cost enzyme production (Fig. 1). The problem with low-cost on-site enzyme production is that while most native fungi grow well with the by-product xylose as a carbon source, they are unable to synthesize large quantities of cellulases in the presence of PPTBs [47].

Fungi synthesize multiple forms of cellulases such as cellobiohydrolases, endoglucanases and $ß$-glucosidases [48-51] only if induced with C6 sugar derivatives [52], cellulose, cellobiose, or trans glycosylated cellobiose products such as sophorose $[52,53]$. Native fungi growing on C5-sugars (xylose) are unable of synthesize cellulases. Fungi synthesize multiple forms of hemicellulases such as xylanases, xylosidases, mannanases, arabinofuranosidases, arabinases and xyloglucanases only if induced with C5-sugar derivatives such as xylan, xylo-oligomers, xylobiose or xylose [54]. Induction of hemicellulases is mainly regulated by the positive transcription factor activator XlnRA [55]. Thus, if one wants to produce large quantities of cellulases by using C5-sugars one has to change the way fungi activate the expression of cellulases by manipulating the activating transcription factors and the promoter that drives cellulase expression [53, 56]. The research reported here resolves this problem by redesigning the Aspergillus nidulans native cellulase gene regulatory circuit, switching the induction mechanism from cellulose to xylose. The strains constructed in this study grow well in xylose, simultaneously producing and secreting large amounts of cellulases. We tested the production of two cellobiohydrolases, two endoglucanases and one $ß$-glucosidase. 


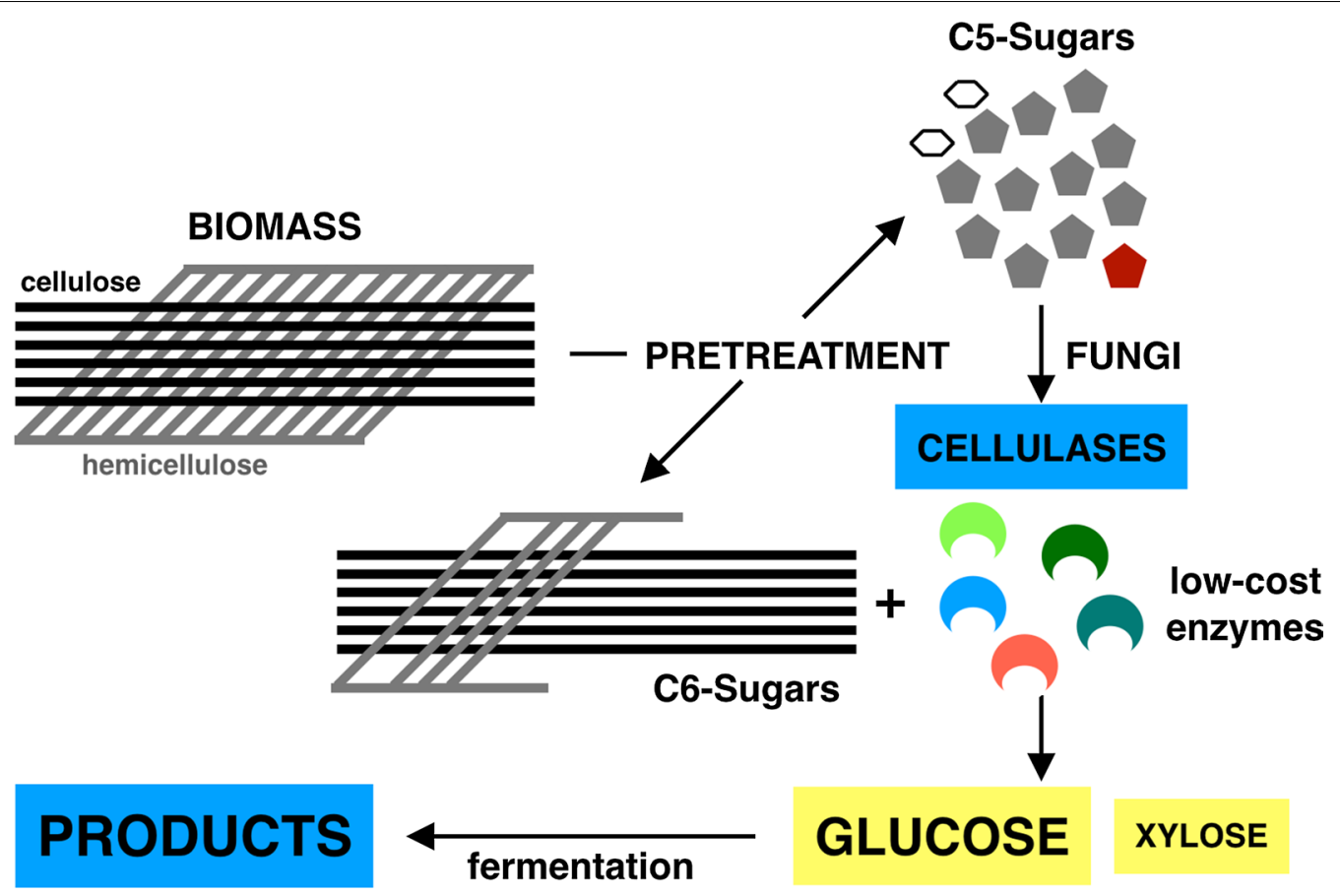

Fig. 1 Schematic of total on-site biomass degradation with low-cost enzyme production. BIOMASS main hydrocarbon components are cellulose and hemicellulose (both account for about $60 \%$ of the total dry weight of biomass [22]. PRETREATMENT technologies make cellulose (C6-sugars) accessible to enzymatic hydrolysis but compromise the integrity of hemicellulose, rendering C5-sugars which could be used to make low-cost enzymes that degrade cellulose (C6-sugars) generating GLUCOSE that is converted into fermentation PRODUCTS

Replacing expensive substrates with a cheap by-product carbon source, PPTB directly derived from LCB pretreatment processes, not only reduces enzyme production costs, but also lowers operational costs, such as off-site enzyme production, purification, concentration, transport and dilution [43-46].

\section{Results and discussion}

In this work, we aimed to switch $A$. nidulans from its natural transcriptional induction regulatory mechanism driven by cellulose signals to a xylose-driven induction mechanism, thus allowing $A$. nidulans to grow on xylose and simultaneously be induced by that same C5-sugar to produce large amounts of cellulases.

To determine which xylanase promoter would most strongly induce cellulase production in the presence of xylose, we replaced $1 \mathrm{~kb}$ of the upstream $c b h C$ (cellobiohydrolase C, AN0494) promoter region with $\sim \mathrm{kb}$ of four xylanase promoter regions, namely xynAp (xylanase A, AN3613), $x y n B p$ (xylanase B, AN9365), xynCp (xylanase $C, A N 1818$ ) and $x y n E p$ (xylanase E, AN7401). In the presence of xylose, $x y n C p$ showed the best performance in secreting cellobiohydrolase (data not shown). Even though all tested promoters secreted cellobiohydrolase $(\operatorname{cbh} C)$ at higher levels than wild-type, the total amount of cellobiohydrolase observed in the medium was less than expected, and some of the promoters were affected by $\mathrm{pH}$ and strong carbon catabolite repression (data not shown).

\section{XInR overexpression and xylose induction}

We thus decided to enhance the expression of client proteins driven by xylose promoters by constructing a $x \ln R$ (xylanase transcription activator) constitutive overexpression strain. $x \ln R$ was placed under the control of the gpdAp promoter, which drives constitutive and strong expression of G3P dehydrogenase (Fig. 2a). For a detailed description of the DNA fragment fusion construction strategy, genomic data and genetic validation of genetic modifications, refer to the Additional file 1.

Figure 2 compares xylanase production of PFIX7, the gpdAp:: $x \ln R$ overexpression strain, with the WT (A773) when growing in media containing $1 \%$ xylose, $1 \%$ hemicellulose or PPTB (2\% xylose, $0.37 \%$ arabinose and $0.28 \%$ glucose). The vegetative growth rates of PFIX7 were comparable to WT (A773) (data not shown) in all C5-sugar sources, but PFIX7 secreted large amounts of xylanases while growing on C5-sugar substrates such as xylose (squares), PPTB (circles) and hemicellulose (diamonds). 


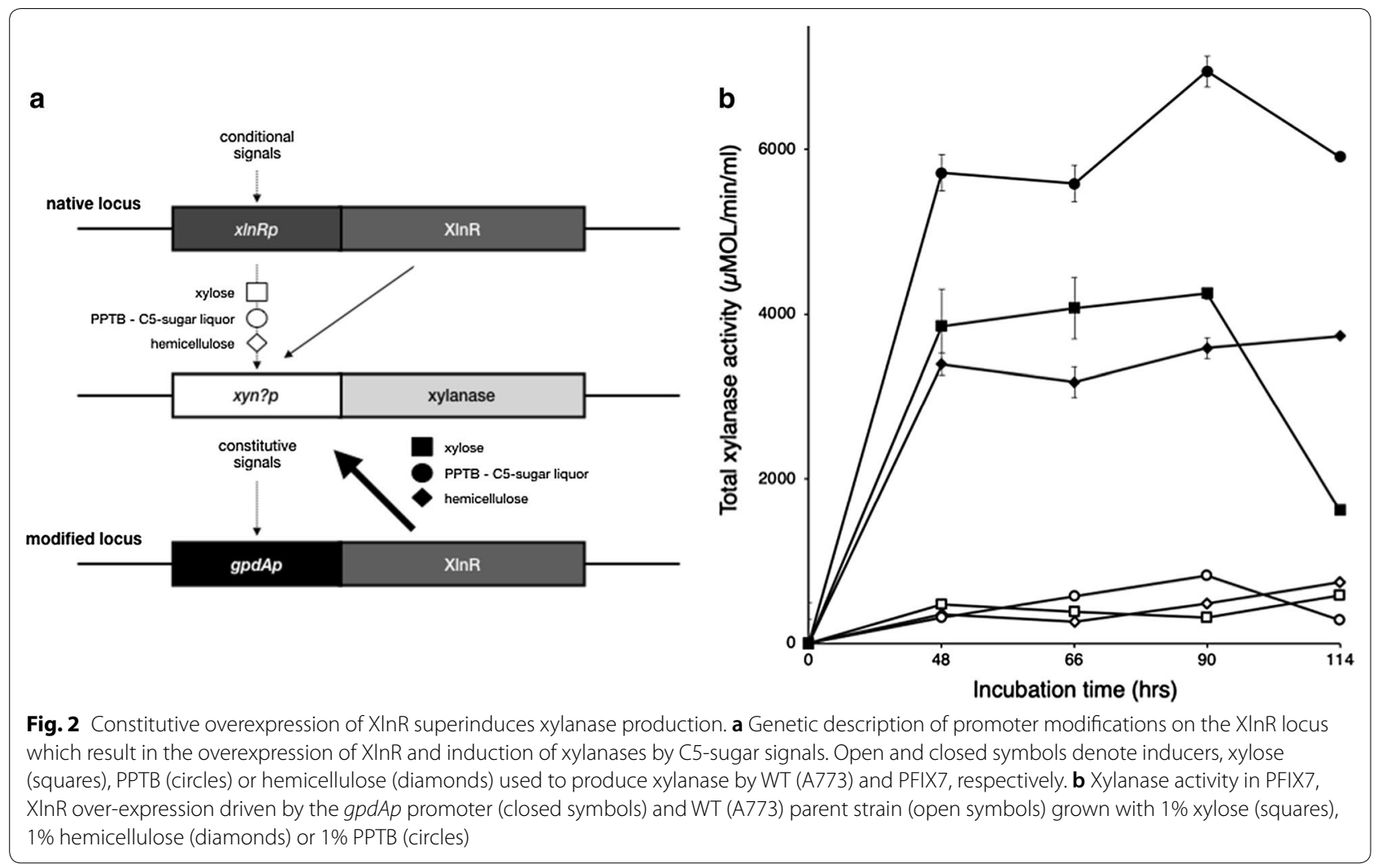

Table 1 Xylanase overexpression and enhanced extracellular protein secretion in PFIX7

\begin{tabular}{llcll}
\hline & $\begin{array}{l}\text { Inducer } \\
\text { Xylose }(\%)\end{array}$ & $\begin{array}{l}\text { Xylanase } \\
\mathbf{U}(\boldsymbol{\mu m o l} / \boldsymbol{\mu l} / \mathbf{m i n})^{\mathbf{a}}\end{array}$ & $\begin{array}{l}\text { Total protein } \\
\boldsymbol{\mu g} / \mathbf{m l}\end{array}$ & $\begin{array}{l}\mathbf{C b h C} \\
\mathbf{U}(\mathbf{p N P C})^{\mathbf{b}}\end{array}$ \\
\hline WT & 2 & $505 \pm 70$ & $259 \pm 78$ & $0.63 \pm 0.29$ \\
& 4 & $628 \pm 85$ & $260 \pm 39$ & $0.36 \pm 0.06$ \\
& 6 & $593 \pm 32$ & $302 \pm 32$ & $0.45 \pm 0.03$ \\
PFIX7 & 2 & $14,023 \pm 4329$ & $1442 \pm 349$ & $4.23 \pm 0.06$ \\
& 4 & $16,248 \pm 3091$ & $1176 \pm 233$ & $4.01 \pm 0.02$ \\
& 6 & $14,958 \pm 2746$ & $1225 \pm 211$ & $2.59 \pm 0.01$ \\
\hline
\end{tabular}

a Substrate was beechwood xylan; ${ }^{\mathrm{b}}$ substrate was pNPC ( $p$-nitrophenyl $\beta$-Dcellobioside)

Table 1 shows xylanase production in WT (A773) and PFIX7 growing on 2, 4 or $6 \%$ xylose. With $2 \%$ xylose, the WT (A773) accumulated $505 \pm 70 \mathrm{U}(\mu \mathrm{mol} /$ $\mu \mathrm{l} / \mathrm{min}$ ) whereas PFIX7 produced $14,023 \pm 4329 \mathrm{U}$ $(\mu \mathrm{mol} / \mu \mathrm{l} / \mathrm{min})$, representing a 26 -fold increase in xylanase accumulation. With $4 \%$ or $6 \%$ xylose, the overaccumulation of xylanase did not increase further. Tamayo-Ramos observed a 200-fold increase in enzyme activity (RhaA) of $A$. nidulans strains overexpressing $\mathrm{X} \ln \mathrm{R}($ gpdAp:: $\ln R)$ and growing on hemicellulose by measuring the reporter $\alpha$-L-rhamnosidase (RhaA) on strains where the $x y n A p$ and $x y n B p$ promoters were fused to rhaA [35].

We measured cellobiohydrolase (CbhC) activity as a control, as $\mathrm{CbhC}$ is not to be under the control of $\mathrm{X} \ln \mathrm{R}$ but under the control of cellulose signals, although it has been reported that in some fungi cellulases are also regulated by XlnR $[57,58]$. Table 1 shows that PFI-X7 CbhC had a 7 (0.63 to $4.23 \mathrm{U}), 11$ (0.36 to $4.01 \mathrm{U}$ )- and 6 ( 0.45 to $2.59 \mathrm{U})$-fold increase in cellobiohydrolase activity in 2, 4 and 6\% xylose respectively. Tamayo-Ramos [35] observed that the total amount of protein secretion was enhanced in XlnR over-expressing strains. Therefore, we also measured the total amount of protein secreted, and observed that PFIX7 displayed a 4- to 6-fold increase in total protein secretion (Table 1). The observed protein secretion augmentation was consistent with the increased $\mathrm{CbhC}$ activity. Thus, the enhanced $\mathrm{CbhC}$ secretion observed in PFIX7 is most likely the result of the improved protein secretion activity driven by $X \ln R$, rather than the specific regulation of cellulase promoters by XlnR. These results corroborate the finding by $[35,57,58]$.

From the data shown in Fig. 2 and Table 1 it seems fair to suggest that XlnR strongly regulates the expression of xylanase activity, while leaving open the possibility that it regulates other activities, such as auxiliary hemicellulases and perhaps cellulases. Moreover, from Fig. 2 and Table 1 
it remains unclear whether $\mathrm{X} \ln \mathrm{R}$ regulates the expression of only one, two or all five xylanases $(x y n A, x y n B, x y n C$, $x y n D$, and $x y n E$ ) encoded by the $A$. nidulans genome [7].

Thus, we decided to determine which enzymes were most strongly secreted by PFIX7 when stimulated with xylose. Figure 3 a shows protein profiles (SDS-PAGE) of enzymes secreted by WT (A773) and PFIX7 growing on xylose. Figure $3 \mathrm{~b}$ lists the spectral counts, determined by LC-MS/MS, of overexpressed protein bands A, B, $\mathrm{C}$, D and E. Remarkably only three proteins were oversecreted in PFIX7 when cultivated on xylose: a chitinase (GH18, band E), xylanase $\mathrm{C}$ (bands $\mathrm{C}$ and $\mathrm{D}$ ), and a protein of unknown function AN1152 (band B). Only small amounts of xylanase $A$, and no other xylanases (B, D or E) were detected by LC-MS/MS (Fig. 3b). In our experiment, which only examined hyper-secreted proteins of $A$. nidulans grown on xylose as the sole carbon source, the XlnR-induced and secreted xylanase (PFIX7) comprised two versions of xylanase C, namely a full-length version $(\sim 34 \mathrm{kDa}$, band $\mathrm{D}$ with CBM1) and a truncated version with a catalytic domain and no CBM1 domain ( $22 \mathrm{kDa}$, band C).

Taking into consideration all of our findings for the overexpression of $\mathrm{X} \ln \mathrm{R}$ in media growing on $\mathrm{C} 5$-sugars (Figs. 2, 3a, b, Table 1), we conclude that overexpressing XlnR (PFIX7) results in predominant secretion of xylanase $\mathrm{C}(\mathrm{XynC})$ when mycelia are grown on xylose. Thus, using the $x y n C p$ promoter to drive the production of client proteins (cellulases) in a strain that overexpresses $\mathrm{XlnR}$ is likely to accumulate large amounts of client proteins.

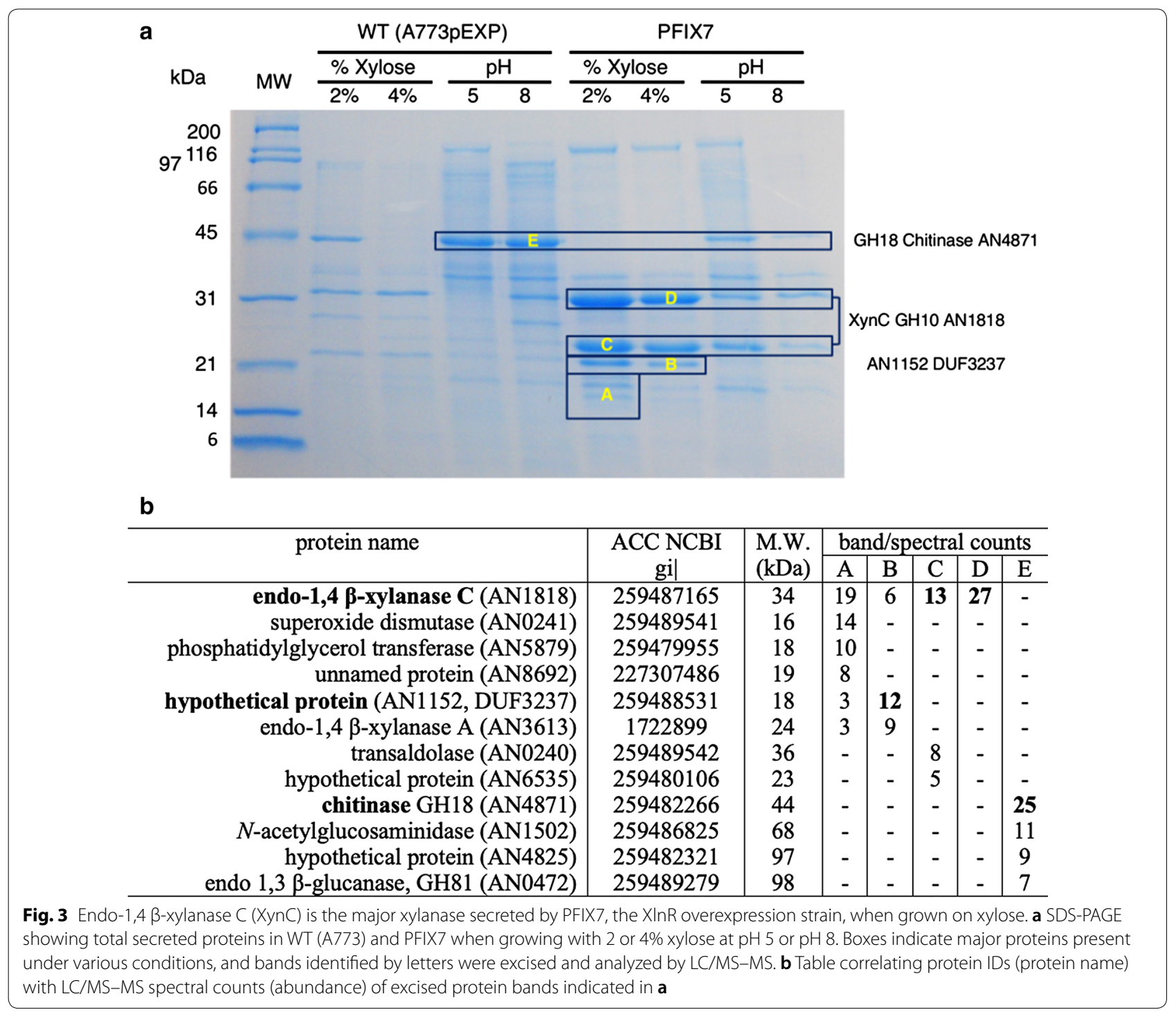




\section{Xylose-induced production of cellulases}

To test the assumption that XlnR overexpression would drive accumulation of potential client proteins driven by the $x y n C p$ promoter, we constructed a series of strains that overproduce five model cellulase genes that are predicted to be necessary to completely convert a cellulose molecule into glucose. Based on the evidence reported by Segato and cols. ([7] and others cited therein), the selected model genes included two cellobiohydrolases ( $\mathrm{CbhB}$ and $\mathrm{CbhC}$ ), two endoglucanases (EglA and EglB) and one $\beta$-glucosidase (BglA). Plasmids bearing $x y n C p:: \mathrm{CP}$ (client protein) constructs were transformed into PFIX7, and transformants were selected based on the amount of secreted client protein $(\mathrm{CP})$.

Figure 4 shows total enzyme activity and protein accumulation of five model genes (CPs) grown in the presence of $2 \%$ xylose. For the endoglucanases EglA and EglB, we found $3908 \pm 190$ and $1570 \pm 60$ enzyme units per milligram total protein, respectively (Fig. 4b). For the cellobiohydrolases $\mathrm{CbhB}$ and $\mathrm{CbhC}$, we found $702 \pm 3$ and $1054 \pm 35$ enzyme units per milligram total protein, respectively (Fig. $4 \mathrm{~b}$ ). For the $\beta$-glucosidase BglA, we found $30,436 \pm 964$ enzyme units per milligram protein (Fig. 4b). SDS-PAGE of crude unfiltered extracts (Fig. 4c) showed that all of the enzymes overaccumulated in the medium. For CbhB, we could not unambiguously detect a clear protein band on SDS-PAGE gels despite detecting increased activity (702 U per milligram protein).

The above result is promising because the engineered strains (PFIX7-EA, PFIX7-EB, PFIX7-CB, PFIX7-CB and PFIX7-BA) accumulate large amounts of client proteins relative to the production of cellulases in the WT (A773) when grown on xylose. The engineered strains, PFIX7EA, PFIX7-EB, PFIX7-CB, PFIX7-CB and PFIX7-BA, showed 35-, 40-, 16-, 9- and 14-fold increases in extracellular specific protein accumulation of $\beta$-glucosidase, endoglucanase A, endoglucanase B, cellobiohydrolase B and cellobiohydrolase $C$, respectively.

\section{Production of xylanases and cellulases with PPTB}

Next, we examined the prospect of using PPTBs both as a C5-sugar carbon source for growth and as an inducer to produce cellulases. Because PPTBs are a byproduct of LCB pretreatments, they primarily contain xylose;

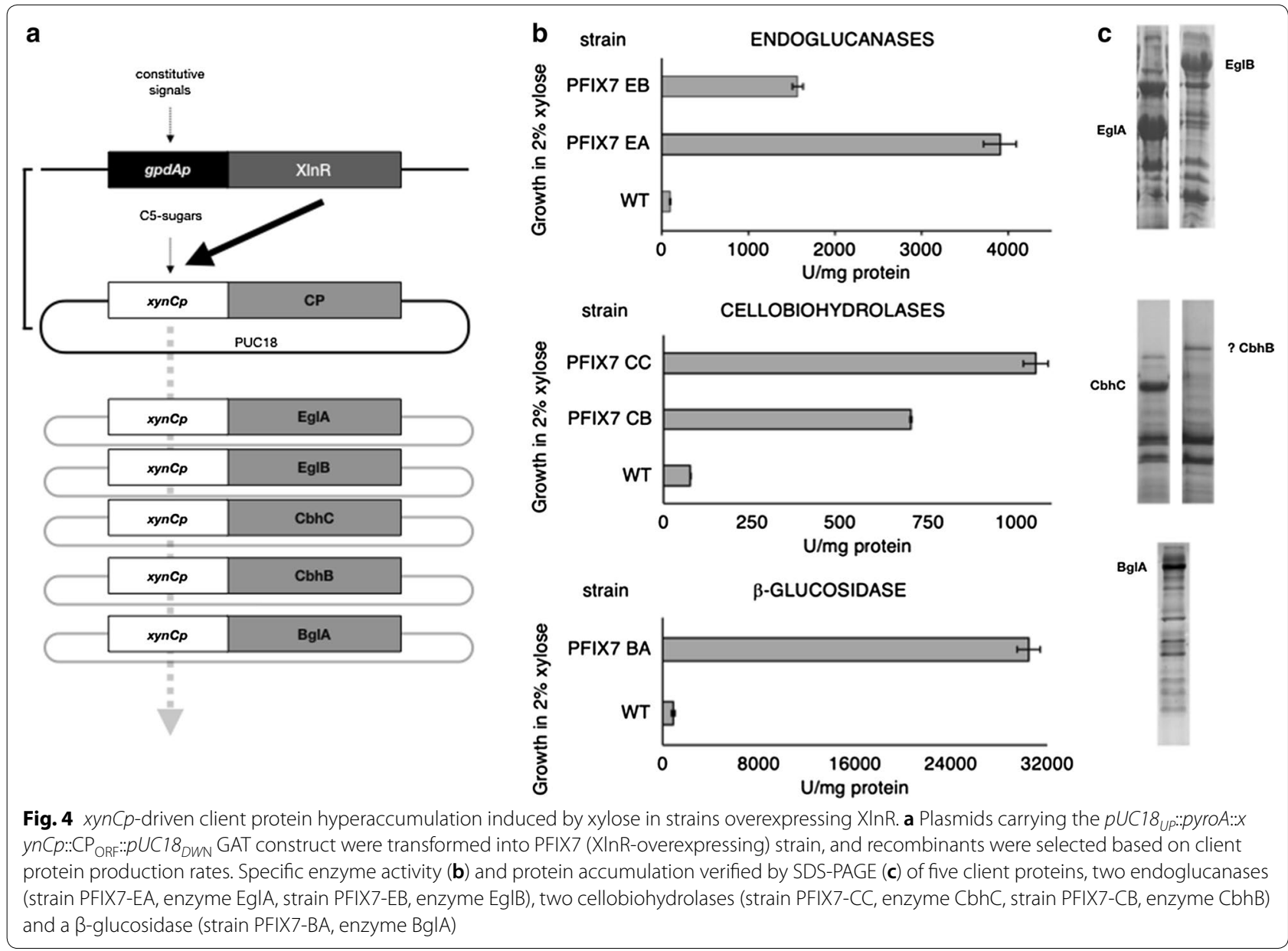


however, other sugars and phenols are also present. The PPTB routinely obtained in our laboratories by treating wheat-straw (LCB) with diluted nitric acid at $160{ }^{\circ} \mathrm{C}$ for $30 \mathrm{~min}$ and then concentrating in a vacuum evaporator contains $162 \mathrm{~g} / \mathrm{l}(76.7 \%)$ of xylose, $29.4 \mathrm{~g} / \mathrm{l}(14 \%)$ of glucose, and $19.7 \mathrm{~g} / \mathrm{l}(9.3 \%)$ of arabinose as potential carbon sources.

We tested two media formulations: a minimal medium composed of Clutterbuck salts [59] amended with xylose (30 g/l) and a PPTB medium containing Clutterbuck salts [59] amended with PPTB (adjusted to $30 \mathrm{~g} / \mathrm{l}$ of xylose, thus corresponding to glucose and arabinose levels of $5.6 \mathrm{~g} / \mathrm{l}$ and $4.2 \mathrm{~g} / \mathrm{l}$, respectively). Three strains were examined for overproduction of enzymes in PPTBs: PFIX7, which due to overexpression of the $\mathrm{X} \ln R$ transcription factor naturally over-produces xylanase; PFIX7EA, which overexpresses endoglucanase A (EglA); and PFIX7-BA, overexpressing ß-glucosidase (BglA).

Table 2 shows that all three strains, PFIX7, PFIX7-EA and PFIX7 BA, produced large amounts of target proteins in xylose-only media, with $24,324 \pm 3479 \mathrm{U}$ of xylanase, $3191 \pm 85 \mathrm{U}$ of endoglucanase and $1749 \pm 93 \mathrm{U}$ of ß-glucosidase produced, respectively. PPTB-containing media also strongly induced target protein production to $29,222 \pm 859 \mathrm{U}$ of xylanase, $4008 \pm 395 \mathrm{U}$ of endoglucanase and $1952 \pm 133 \mathrm{U}$ of $ß$-glucosidase, respectively.

The amounts of xylanase, endoglucanase and B-glucosidase produced in xylose-only and PPTB-amended media were similar (Table 2), indicating that the presence of other sugars in PPTB such as glucose and arabinose did not negatively affect the enzyme production process. Table 2 also shows that carbon source consumption was slightly different. In xylose-only media, consumption was almost complete, above 90\%, but in PPTB-containing media, consumption was slightly reduced but still above $80 \%$.
For comparison purposes (Table 2) we report our enzyme productivity measurements in various ways: $\mathrm{U} / \mathrm{ml}$ (amount of enzyme per $\mathrm{mL}$ of medium), $\mathrm{U}$ (total amount produced in the fermentation system), U/g (of biomass (mycelium) and $\mathrm{U} / \mathrm{mg}$ (of total amount of secreted protein). In Table 3 we tried to gather the best published enzyme production rates for xylanases, endoglucanases and $B$-glucosidases produced in different protein expression hosts with various inducers. In PPTB, our system produced $4666 \mathrm{U} / \mathrm{mg}$ protein of xylanases. In comparison, xylanases produced by Pichia pastoris range between 923 and $1533 \mathrm{U} / \mathrm{mg}$ of xylanase, and xylanase production in A. awamori using the PFE2 expression plasmid reached $149.6 \mathrm{U} / \mathrm{mg}$. For endoglucanases, our PPTB system produced $385.9 \mathrm{U} / \mathrm{mg}$ protein, whereas endoglucanases produced in P. pastoris, Escherichia coli or A. nidulans reached between 6.78 and $256 \mathrm{U} / \mathrm{mg}$ of endo enzymes. Our PPTB system produced $206.4 \mathrm{U} / \mathrm{mg}$ protein of $ß$-glucosidases, whereas $P$. pastoris produced 66.6 to $258 \mathrm{U} / \mathrm{mg}$.

\section{Conclusion}

Here we report on a succession of genetic interventions in Aspergillus nidulans that redesign the natural regulatory circuitry of cellulase genes in such a way that recombinant strains use C5-sugar liquors (PPTB) to grow a vegetative tissue and simultaneously produce large amounts of cellulases. Five cellulases, two cellobiohydrolases ( $\mathrm{CbhB}$ and $\mathrm{CbhC}$ ), two endoglucanases (EglA and EglB) and a $\beta$-glucosidase (BglA) accumulate at high titers when cultivated with PPTB C5-sugars. Cellulase production rates with $\mathrm{PPTB}$ was comparable to other heterologous expression systems, P. pastoris, E. coli and fungal cell factories. Recouping PPTBs to streamline the biomass degradation process by integrating pretreatment technologies with the use of $\mathrm{C} 5$-sugars to produce

Table 2 Cellulase and xylanase production in media containing C5-sugars

\begin{tabular}{|c|c|c|c|c|c|c|}
\hline & \multicolumn{2}{|c|}{ Enzyme measurements } & \multirow{3}{*}{$\begin{array}{l}\text { Secreted } \\
\text { Proteins } \\
\text { g/l }\end{array}$} & \multirow{3}{*}{$\begin{array}{l}\text { Spent } \\
\text { Sugar } \\
\%\end{array}$} & \multirow{2}{*}{\multicolumn{2}{|c|}{$\frac{\text { Enzyme }}{\text { Productivity }}$}} \\
\hline & \multirow{2}{*}{$\begin{array}{l}\text { Activity } \\
\mathrm{U} / \mathrm{ml}\end{array}$} & \multirow{2}{*}{$\begin{array}{l}\text { Specific } \\
\text { U/mg prot }\end{array}$} & & & & \\
\hline & & & & & $\mathrm{U} / \mathrm{lh}$ & $\mathrm{Y}_{\mathrm{P} / \mathrm{S}}$ \\
\hline \multicolumn{7}{|c|}{ Xylose amended minimal medium } \\
\hline PFI-X7 & $2760 \pm 6^{a}$ & 4058 & 0.68 & 96 & 38,333 & 35,646 \\
\hline PFIX7-EA & $283 \pm 26^{b}$ & 340.9 & 0.83 & 96 & 3930 & 4598 \\
\hline PFIX7-BA & $155 \pm 18^{c}$ & 176,1 & 0.88 & 93 & 2152 & 2662 \\
\hline \multicolumn{7}{|c|}{ PPTB amended minimal medium } \\
\hline PFI-X7 & $2473 \pm 51$ & 4666 & 0.53 & 80 & 34,347 & 49,420 \\
\hline PFIX7-EA & $328 \pm 14$ & 385.9 & 0.85 & 86 & 4556 & 6132 \\
\hline PFIX7-BA & $161 \pm 7$ & 206.4 & 0.78 & 83 & 2236 & 3239 \\
\hline
\end{tabular}

${ }^{a}$ Xylanase activity; ${ }^{\mathrm{b}}$ endoglucanase activity; ${ }^{\mathrm{c}}$ beta-glucosidase activity, ${ }^{\mathrm{d}} \mathrm{U}$ per $\mathrm{mg}$ of secreted protein 
Table 3 Heterologous protein expression (and/or)/secretion of xylanases, endoglucanases and B-glucosidases

\begin{tabular}{|c|c|c|c|c|c|c|}
\hline \multirow[t]{2}{*}{ Enzyme/class } & \multirow[t]{2}{*}{ Gene (ORF) source } & \multirow{2}{*}{$\begin{array}{l}\text { Expression host/ } \\
\text { expression system }\end{array}$} & \multirow[t]{2}{*}{ Inducer } & \multicolumn{2}{|c|}{ Activity } & \multirow[t]{2}{*}{ Refs. } \\
\hline & & & & $\#$ & Unit & \\
\hline \multicolumn{7}{|l|}{ Xylanases } \\
\hline XYN2 & T. reesei & P. pastoris/PICZ & Methanol & 1435 & $\mathrm{U} / \mathrm{mg}$ & [75] \\
\hline xynC & A. nidulans & P. pastoris/PICZ & Methanol & 923 & $\mathrm{U} / \mathrm{ml}$ & [76] \\
\hline $\mathrm{GH} 11$ & M. thermophila & P. pastoris/PICZ & Methanol & 1533.7 & $\mathrm{U} / \mathrm{mg}$ & [77] \\
\hline $\mathrm{GH} 11$ & A. clavatus & A. awamori/pFE2 & Maltose & 149.6 & $\mathrm{U} / \mathrm{mg}$ & [78] \\
\hline \multicolumn{7}{|l|}{ Endoglucanases } \\
\hline GH6 & C. cinerea & P. pastoris/PICZ & Methanol & 118.75 & $\mathrm{U} / \mathrm{mg}$ & [79] \\
\hline GH5 & T. aurantiacus & P. pastoris/PICZ & Methanol & 190 & $\mathrm{U} / \mathrm{mg}$ & {$[80]$} \\
\hline $\mathrm{GH} 12$ & A. terreus & A. nidulans/pEXPYR & Maltose & 256 & $\mathrm{U} / \mathrm{mg}$ & [81] \\
\hline \multicolumn{7}{|l|}{ B-Glucosidases } \\
\hline $\mathrm{GH} 3$ & M. thermophila & P.pastoris/PICZ & Methanol & 258.7 & $\mathrm{U} / \mathrm{mg}$ & {$[82]$} \\
\hline $\mathrm{GH} 3$ & P. thermophila & P.pastoris/PICZ & Methanol & 66.6 & $\mathrm{U} / \mathrm{mg}$ & [83] \\
\hline $\mathrm{GH} 1$ & P. thermophila & P.pastoris/PICZ & Methanol & 192.7 & $\mathrm{U} / \mathrm{mg}$ & [84] \\
\hline
\end{tabular}

the enzymes needed to digest pretreated biomass should result in significant cost reductions applied to the entire biomass degradation process. We are currently investigating the feasibility of large-scale production of cellulases with PPTBs.

\section{Materials and methods}

\section{Chemicals and specialty chemicals}

General chemicals, cellulosic and hemicellulosic substrates were purchased from the best source possible, Sigma Aldrich (St. Louis, MO) and Megazyme (Ireland, UK). Phosphoric acid swollen cellulose (PASC) was prepared according to [60].

Wheat straw was harvested in 2015 from a local farmer in Rhineland Palatinate (Bad Kreuznach, Germany). The composition was determined according to the method suggested by the National Renewable Energy Laboratory (NREL) for measurement of structural carbohydrates and lignin [61]. The wheat straw had $37.1 \%(w / w)$ cellulose, $22.3 \%(\mathrm{w} / \mathrm{w})$ hemicellulose, $16.8 \%(\mathrm{w} / \mathrm{w})$ lignin, $9 \%(\mathrm{w} / \mathrm{w})$ extractives and $4.3 \%(\mathrm{w} / \mathrm{w})$ ash. HPLC analytics were done with the Metacarb $87 \mathrm{H}$ column $(300 \mathrm{~mm} \times 7.8 \mathrm{~mm})$ purchased from Agilent Inc. (Santa Clara, CA, USA). All used chemicals were purchased from VWR International (Radnor, PA, USA).

\section{Production of the xylose-containing liquefied wheat straw hydrolysate (PPTB)}

The PPTB, pentosan containing pre-treated biomass liquor was prepared by diluted acid hydrolysis of wheat straw in a 100-1 stainless steel reactor. The vessel was heated with direct steam injection until the desired temperature was reached. In a previous study, the optimized treatment process parameters for high xylose and lowby-product concentration were estimated [62]. Briefly, dried wheat straw $(15 \% \mathrm{v} / \mathrm{w}$, dry matter content) and diluted nitric acid $(0.45 \% \mathrm{v} / \mathrm{v})$ was heated up at $160{ }^{\circ} \mathrm{C}$ for $30 \mathrm{~min}$. After the pretreatment the pentose-rich liquor was separated from the solid biomass. The pre-hydrolysate solution was concentrated in a rotary evaporator at $75{ }^{\circ} \mathrm{C}$ and 110 mbar to enhance the storability of the pre-hydrolysate. The concentrated solution contained $162 \mathrm{~g} / \mathrm{l}$ xylose, $29.4 \mathrm{~g} / \mathrm{l}$ glucose and, $19.7 \mathrm{~g} / \mathrm{l}$ arabinose. Pretreatment by-products such as furfural and 5-HMF were removed through the evaporation process. The concentrated hydrolysate was stored at $-20^{\circ} \mathrm{C}$.

\section{Strain construction}

Standard A. nidulans minimal medium (MM) and general cultivation techniques were used throughout this work and are based on the work by Guido Pontecorvo [63, 64] and John Clutterbuck [59]. All strains constructed in this work were derived from $A$. nidulans A773 (wA3, pyrG89, pyroA4) purchased from the Fungal Genetics Stock Center (FGSC, St. Louis, MO). All gene models and promoters were from Aspergillus nidulans FGSC4 (https://www.ncbi.nlm.nih.gov/assembly/ GCF_000149205.2) and analyzed using the AspGD database (http://aspgd.org [65]) Primers and Gibson Assembly hybrid primers were designed using the NEB Builder Assembly Tool (http://nebuilder.neb.com).

Three types of strains were constructed in this study; First the resident $\mathrm{CbhC}$ (AN0494) promoter $(c b h C p)$ was replaced with four xylanase promoters $(x y n A B C E p)$ in such a way that recombinant strains induce the production of cellobiohydrolase by xylose, second a $X \ln R_{(\mathrm{ORF})}$ 
overexpression strain (PFIX7) was constructed by pabaA ectopic integration of a $g p d A p:: \mathrm{Xln}_{(\mathrm{ORF})} \mathrm{DNA}$ fragment, and third, xylose induced client protein constructs were randomly introduced into a XlnR overexpressing strain (PFIX7). For a detailed description of DNA fragment fusion construction strategy, genomic data and genetic validation of genetic modifications refer to Additional file 1.

In all types of strain constructions, a linear hybrid recombinant DNA fragment was synthesized using Gibson Assembly Technology, GAT [66, 67] using hybrid primers, Gibson Assembly Master Mix (New England Biolabs, US) and Phusion DNA Polymerase (New England Biolabs, US). DNA fragment size and DNA sequence verified hybrid DNA fragments were transformed into A773 or PFIX7 protoplasts. In the case of promoter replacements, a single gene replacement event at the $c b h 1$ locus was selected for each $x y n(p)$ promoter replacement by uracil/uridine sufficiency and by diagnostic PCR showing single integration (replacement) into the $c b h 1$ locus. For the $\mathrm{X} \ln R$ overexpression, the hybrid DNA fragment was integrated into the pabaA locus by a double crossover event disrupting it. Recombinants with a single gene replacement event were searched with diagnostic PCR and the resulting strain PFIX7 tested for XlnR over-expression.

For the client protein xylose induced strains we created plasmids carrying the pUC18 ${ }_{U P}:$ pyroA: $x y n C p::$ CLIENT $_{\mathrm{ORF}}:: p U C 18_{D W N}$ GAT construct that was transformed into PFIX7 (XInR overexpressing) strain and recombinants selected based on the level of client protein production rates. Even though we did not check for multiple integration events in single transformants we screened at least 100 transformants for high secretion levels of client proteins.

\section{Preparation of total extracellular protein extracts}

Unless otherwise stated, $5 \mathrm{ml}$ of extracellular fluid (medium) harvested from mycelia grown for 24, 36 or $48 \mathrm{~h}$ were treated with $3 \mathrm{kDa}$ cutoff Nanosep ${ }^{\circledR}$ ultrafiltration Omega ${ }^{\mathrm{TM}}$ membrane columns (PALL Corp. USA) and washed with $500 \mu \mathrm{l}$ of $50 \mathrm{mM}$ ammonium acetate $\left(\mathrm{NH}_{4} \mathrm{CH}_{3} \mathrm{CO}_{2}\right)$ buffer $\mathrm{pH} 5$ before $10 \times$ concentration to a final volume of $50 \mu \mathrm{l}$.

\section{Protein quantification and SDS-polyacrylamide gel electrophoresis}

Total protein content was measured in microtiter dishes using the Bio-Rad assay reagent (Bio-Rad Laboratories, USA), using a procedure based on the Bradford method $[68,69]$ with bovine serum albumin as standard. Absorption was measured using a UV-Vis 96-well plate reader (Tecan Infinite M200, Männedorf, Switzerland) at
$595 \mathrm{~nm}$. Quality of total extracellular protein extracts was validated for integrity by SDS polyacrylamide gel electrophoresis according to Shapiro [70].

\section{Liquid chromatography-tandem mass spectrometry}

For LC-MS/MS analysis bands of a fully resolved SDSPAGE gel (shown in Fig. 3a) were excised and processed for LC-MS/MS according to [71] with modifications. Isolated gel bands were reduced with Tris (2-carboxyethyl) phosphine, alkylated by 2-iodoacetamide, digested for 6-16 $\mathrm{h}$ with $8 \mu \mathrm{g} / \mathrm{ml}$ trypsin using ammonium bicarbonate buffer and analyzed by LC-MS/MS using LTQ-Orbitrap XL hybrid mass spectrometer (Thermo Scientific). The LC-MS/MS raw files were used for database Mascot (version 2.2.04, Matrix Science, London UK) searches run on a NCBI Aspergillus nidulans FGSC4 subsets. Searches were validated using Scaffold (version 4.0.7, Proteome Software Inc. Portland, OR) with a protein threshold of 5\% FDR and a peptide threshold of $99 \%$.

\section{Free sugar (reducing end) determinations}

Free sugar determinations were used in two types of experiments: (1) to determine the activity of enzymes that use a non-reducing substrate releasing reducing products (sugars) and (2) to quantitate the amount of reducing sugar consumed. In both cases we used the dinitrosalicylic acid (DNS) assay developed by Sumner and Graham [72] for detection of reducing sugars. The DNS reducing sugar assay was based on the method described by Miller [73] and adapted to a microtiter dish scale. The DNS reagent we used contained $0.75 \%$ dinitrosalicylic acid, $0.5 \%$ phenol, $0.5 \%$ sodium metabisulfite, and $1.4 \%$ sodium hydroxide, $21 \%$ sodium and potassium tartarate.

\section{Determination of enzyme activities}

Xylanase and endoglucanase activity were determined using beechwood hemicellulose or carboxymethylcellulose $(\mathrm{CMC})$ as a substrate, respectively and activity measured by the release of reducing sugars that react with DNS [73]. Briefly to $300 \mu \mathrm{l}$ of $1 \%$ beechwood xylan or $1 \%$ CMC, $50 \mathrm{mM}$ ammonium acetate buffer $10-50 \mu \mathrm{l}$ of total extracellular protein extract (treated as described in 2.2) was added and reactions incubated for 10,20 or $30 \mathrm{~min}$ at $45{ }^{\circ} \mathrm{C}$ prior to the addition of $300 \mu \mathrm{L}$ of DNS. Control reactions (blanks that determine the presence of reducing sugars in the starting mixture) contained all the same reagents except that DNS was added prior to the addition of enzyme sample. To determine the amount of reducing sugar produced during the enzyme catalyzed reaction the $\mathrm{ABS}^{540 \mathrm{~nm}}$ of the control was subtracted from the enzyme reaction and resulting net gain in $\mathrm{ABS}^{540 \mathrm{~nm}}$ converted into enzyme units $\mu \mathrm{mol} / \mathrm{min} / \mu \mathrm{g}$. protein. 
Cellobiohydrolase and $\beta$-glucosidase were assayed using $p$ NPC, $p$-nitrophenyl $\beta$-D-cellobioside or $p$-nitrophenyl $\beta$-D-glucoside (pNPG) (Sigma Aldrich, St. Louis $\mathrm{MO})$ ) as a substrate, respectively and activity measured by the release of $p$-nitrophenyl that absorbs at $\mathrm{ABS}^{420 \mathrm{~nm}}$ on a TECAN microwell reader. Briefly to $570 \mu \mathrm{l}$ of $4 \mathrm{mM}$ $p$ NPC, $50 \mathrm{mM}$ ammonium acetate buffer $5-10 \mu \mathrm{l}$ of total extracellular protein extract (treated as described in 2.2) was added and reactions incubated for 5,10 or $30 \mathrm{~min}$ at $45^{\circ} \mathrm{C}$ prior to the addition of $60 \mu \mathrm{l}$ of $2 \mathrm{M}$ sodium carbonate. Control reactions contained all the same reagents except that $2 \mathrm{M}$ sodium carbonate was added prior to the addition of enzyme sample. To determine the amount of $p$-nitrophenyl produced during the enzyme catalyzed reaction the $\mathrm{ABS}^{420 \mathrm{~nm}}$ of the control was subtracted from the enzyme reaction and resulting net gain in $\mathrm{ABS}^{420 \mathrm{~nm}}$ converted into enzyme units $\mu \mathrm{mol} / \mathrm{min} / \mu \mathrm{g}$ protein.

\section{Production of xylanases and cellulases with PPTB}

Fermentation experiments examining the here constructed strains, PFIX7, PFIX7-EA and PFIX7-BA using PРТВ were done in shaker flasks. The concentrated pre-hydrolysate was adjusted with water to a $30 \mathrm{~g} / \mathrm{l}$ xylose-concentration and amended with mineral salts as described in Clutterbuck [59]. The inoculum was $1 \times 10^{5}$ spores $/ \mathrm{ml}$ medium and fermentations were carried out at $37{ }^{\circ} \mathrm{C}$ in an orbital shaker at $120 \mathrm{rpm}$ for $72 \mathrm{~h}$. Samples were taken and the supernatants stored at $-20{ }^{\circ} \mathrm{C}$ for later analysis. All experiments were done in triplicates.

\section{Determination of the phenolic content and sugar concentrations}

The total phenolic content was analyzed according to the Folin-Ciocalteau method [74]. Briefly, properly diluted samples $(200 \mu \mathrm{l})$ were added to distilled water $(800 \mu \mathrm{l})$ and mixed with Folin-Ciocalteau regent $(500 \mu \mathrm{l})$. Sodium carbonate $(2.5 \mathrm{ml}, 20 \% \mathrm{w} / \mathrm{v})$ was added after $3 \mathrm{~min}$ and the samples were incubated in the dark for $30 \mathrm{~min}$. The absorbance was measured at $725 \mathrm{~nm}$ using a photometer. Vanillin was used as external standard.

The concentrations of glucose, xylose, arabinose, acetic acid, furfural and 5-HMF in the pre-hydrolysate and cultivation samples were determined by HPLC measurements (Agilent 1200 Series). The HPLC was equipped with a pump unit, an autosampler unit, a refractive index detector unit and a computer software-based integration system (LC ChemStation). The MetaCarb $87 \mathrm{H}$ column was maintained at $80{ }^{\circ} \mathrm{C}$ at the flow rate of $0.5 \mathrm{ml} / \mathrm{min}$ with $0.05 \mathrm{M} \mathrm{H}_{2} \mathrm{SO}_{4}$ as the mobile phase. Peaks detected by refractive index were identified and quantified by comparison with the retention times of authentic standards.

\section{Supplementary information}

Supplementary information accompanies this paper at https://doi. org/10.1186/s12934-019-1243-5.

Additional file 1. Construction of hemicellulose induced cellulase production Aspergillus nidulans strains.

\begin{abstract}
Abbreviations
5-HMF: 5-hydroxymethylfurfural; ABS: absorbance; BglA: $\beta$-glucosidase; C6-sugars: glucose containing liquors; C5-sugars: pentose containing liquors; CbhB and CbhC: cellobiohydrolase B and C; CMC: carboxymethylcellulose; DNS: dinitro salicylic acid; EgIA and EglB: endoglucanase A and B; GAT: gibson assembly technology; gpdAp: G3P dehydrogenase promoter; HPLC: high performance liquid chromatography; LCB: lignocellulosic biomass; LC-MS/ MS: liquid chromatography-tandem mass spectrometry; PASC: phosphoric acid swollen cellulose; PCR: polymerase chain reaction; $p$ NPC: $p$-nitrophenyl $\beta$-D-cellobioside; $p N P G$ : $p$-nitrophenyl $\beta$-D-glucoside; PPTB: pentosan containing pre-treated biomass liquor; SDS: sodium dodecyl sulfate; SDS-PAGE: SDS polyacrylamide gel electrophoresis; WT: wild type A773 strain; XynC: xylanase $C_{;}$xyn $C p$ : xylanase $C$ promoter; $X \mid n R$ : binuclear zinc finger transcription factor.
\end{abstract}

\section{Acknowledgements}

We acknowledge receiving generous funds from PFI, Prüf und Forschungsinstitut, Pirmasens, (Germany), as part of a consulting contract with RAP in 2014. The funds were provided from the "Bundesministerium für Ernährung and Landwirtschaft" according to a research project (FNR 22027312). We kindly acknowledge the helping hands of Mathew Cabeen, Mark Wilkins and Jerreme Jackson that read our manuscript and made important suggestions that made this article hopefully understandable to a broad audience spanning a wide cast of areas which this research embraces.

\section{Authors' contributions}

MM designed and coordinated the study, RAP and JL planned and carried out the Molecular Genetics Experiments, PB and SD planned and carried out biochemical engineering experiments. MM, RAP, JL, SD and PB co-wrote, coreviewed the manuscript. All authors read and approved the final manuscript.

Funding

Funding sources have been addressed in "Acknowledgements".

Availability of data and materials

All data generated or analyzed during this study are included in this published article and its Additional file 1.

Ethics approval and consent to participate

Not applicable.

\section{Consent for publication}

Not applicable.

\section{Competing interests}

The authors declare that they have no competing interests.

\section{Author details}

${ }^{1}$ Prüf- und Forschungsinstitut Pirmasens e.V., Marie-Curie-Strasse 19, 66953 Pirmasens, Germany. ${ }^{2}$ Department of Microbiology \& Molecular Genetics, Oklahoma State University, Stillwater, OK 74078, USA.

Received: 18 June 2019 Accepted: 24 October 2019

Published online: 07 November 2019

References

1. Bar-On YM, Phillips R, Milo R. The biomass distribution on Earth. Proc Natl Acad Sci USA. 2018;115(25):6506-11.

2. Jadidzadeh A, Serletis A. The global crude oil market and biofuel agricultural commodity prices. J Econ Asymmetr. 2018;18:e00094. 
3. Ellila S, Fonseca L, Uchima C, Cota J, Goldman GH, Saloheimo M, et al. Development of a low-cost cellulase production process using Trichoderma reesei for Brazilian biorefineries. Biotechnol Biofuels. 2017;10:30.

4. Lynd LR, Laser MS, Bransby D, Dale BE, Davison B, Hamilton R, et al. How biotech can transform biofuels. Nat Biotechnol. 2008;26(2):169-72.

5. Sheldon RA. The road to biorenewables: carbohydrates to commodity chemicals. Acs Sustain Chem Eng. 2018;6(4):4464-80.

6. Cragg SM, Beckham GT, Bruce NC, Bugg TD, Distel DL, Dupree P, et al. Lignocellulose degradation mechanisms across the Tree of Life. Curr Opin Chem Biol. 2015;29:108-19.

7. Segato F, Damasio AR, de Lucas RC, Squina FM, Prade RA. Genomics review of holocellulose deconstruction by aspergilli. Microbiol Mol Biol Rev. 2014;78(4):588-613.

8. Ding SY, Liu YS, Zeng Y, Himmel ME, Baker JO, Bayer EA. How does plant cell wall nanoscale architecture correlate with enzymatic digestibility? Science. 2012;338(6110):1055-60.

9. Ding SY, Himmel ME. The maize primary cell wall microfibril: a new model derived from direct visualization. J Agric Food Chem. 2006;54(3):597-606.

10. Arantes $\mathrm{V}$, Saddler JN. Access to cellulose limits the efficiency of enzymatic hydrolysis: the role of amorphogenesis. Biotechnol Biofuels. 2010;3(4):4.

11. Bhutto AW, Qureshi K, Harijan K, Abro R, Abbas T, Bazmi AA, et al. Insight into progress in pre-treatment of lignocellulosic biomass. Energy. 2017;122:724-45.

12. Chen HY, Liu JB, Chang X, Chen DM, Xue Y, Liu P, et al. A review on the pretreatment of lignocellulose for high-value chemicals. Fuel Process Technol. 2017:160:196-206.

13. Ciesielski PN, Matthews JF, Tucker MP, Beckham GT, Crowley MF, Himmel $\mathrm{ME}$, et al. 3D electron tomography of pretreated biomass informs atomic modeling of cellulose microfibrils. ACS Nano. 2013;7(9):8011-9.

14. Jin S, Zhang G, Zhang P, Fan S, Li F. High-pressure homogenization pretreatment of four different lignocellulosic biomass for enhancing enzymatic digestibility. Bioresour Technol. 2015;181:270-4.

15. Yunus R, Salleh SF, Abdullah N, Biak DR. Effect of ultrasonic pre-treatment on low temperature acid hydrolysis of oil palm empty fruit bunch. Bioresour Technol. 2010;101(24):9792-6.

16. Williams $\mathrm{O}$, Newbolt $\mathrm{G}$, Eastwick C, Kingman S, Giddings D, Lormor $\mathrm{S}$, et al. Influence of mill type on densified biomass comminution. Appl Energy. 2016;182:219-31.

17. Kato DM, Elia N, Flythe M, Lynn BC. Pretreatment of lignocellulosic biomass using Fenton chemistry. Bioresour Technol. 2014;162:273-8.

18. Loow YL, WU TY, Jahim JM, Mohammad AW, Teoh WH. Typical conversion of lignocellulosic biomass into reducing sugars using dilute acid hydrolysis and alkaline pretreatment. Cellulose. 2016;23(3):1491-520.

19. Xu HF, Li B, Mu XD. Review of alkali-based pretreatment to enhance enzymatic saccharification for lignocellulosic biomass conversion. Ind Eng Chem Res. 2016:55(32):8691-705.

20. Chen HZ, Liu ZH. Steam explosion and its combinatorial pretreatment refining technology of plant biomass to bio-based products. Biotechnol J. 2015;10(6):866-85.

21. Jonsson $\sqcup$, Martin C. Pretreatment of lignocellulose: formation of inhibitory by-products and strategies for minimizing their effects. Bioresour Technol. 2016:199:103-12.

22. Auxenfans T, Cronier D, Chabbert B, Paes G. Understanding the structural and chemical changes of plant biomass following steam explosion pretreatment. Biotechnol Biofuels. 2017;10:36.

23. Balan V, Bals B, Chundawat SP, Marshall D, Dale BE. Lignocellulosic biomass pretreatment using AFEX. Methods Mol Biol. 2009;581:61-77.

24. Jin M, Gunawan C, Balan V, Lau MW, Dale BE. Simultaneous saccharification and co-fermentation (SSCF) of AFEX(TM) pretreated corn stover for ethanol production using commercial enzymes and Saccharomyces cerevisiae 424A(LNH-ST). Bioresour Technol. 2012:110:587-94.

25. Cha YL, Yang J, Ahn JW, Moon YH, Yoon YM, Yu GD, et al. The optimized $\mathrm{CO}_{2}$-added ammonia explosion pretreatment for bioethanol production from rice straw. Bioprocess Biosyst Eng. 2014;37(9):1907-15.

26. Kang $Y$, Bansal $P$, Realff $M$, Bommarius $A$. $\mathrm{SO}_{2}$-catalyzed steam explosion: the effects of different severity on digestibility, accessibility, and crystallinity of lignocellulosic biomass. Biotechnol Prog. 2013;29:909-16.

27. Hall M, Bansal P, Lee JH, Realff MJ, Bommarius AS. Cellulose crystallinity - a key predictor of the enzymatic hydrolysis rate. FEBS J. 2010:277(6):1571-82.
28. Bischof RH, Ramoni J, Seiboth B. Cellulases and beyond: the first 70 years of the enzyme producer Trichoderma reesei. Microb Cell Fact. 2016:15(1):106.

29. Davy AM, Kildegaard HF, Andersen MR. Cell factory engineering. Cell Syst. 2017:4(3):262-75.

30. Demain AL, Vaishnav P. Production of recombinant proteins by microbes and higher organisms. Biotechnol Adv. 2009;27(3):297-306.

31. Nevalainen KM, Te'o VS, Bergquist PL. Heterologous protein expression in filamentous fungi. Trends Biotechnol. 2005;23(9):468-74.

32. Zhang J, Zhang G, Wang W, Wang W, Wei D. Enhanced cellulase production in Trichoderma reesei RUT C30 via constitution of minimal transcriptional activators. Microb Cell Fact. 2018;17(1):75.

33. Druzhinina IS, Kubicek CP. Genetic engineering of Trichoderma reesei cellulases and their production. Microb Biotechnol. 2017;10(6):1485-99.

34. Segato F, Damasio AR, Goncalves TA, de Lucas RC, Squina FM, Decker $\mathrm{SR}$, et al. High-yield secretion of multiple client proteins in Aspergillus. Enzyme Microb Technol. 2012;51(2):100-6.

35. Tamayo-Ramos JA, Orejas M. Enhanced glycosyl hydrolase production in Aspergillus nidulans using transcription factor engineering approaches. Biotechnol Biofuels. 2014:7(1):103.

36. Yoon J, Kimura S, Maruyama J, Kitamoto K. Construction of quintuple protease gene disruptant for heterologous protein production in Aspergillus oryzae. Appl Microbiol Biotechnol. 2009;82(4):691-701.

37. Yoon J, Maruyama J, Kitamoto K. Disruption of ten protease genes in the filamentous fungus Aspergillus oryzae highly improves production of heterologous proteins. Appl Microbiol Biotechnol. 2011;89(3):747-59.

38. Knuf C, Nielsen J. Aspergilli: systems biology and industrial applications. Biotechnol J. 2012;7(9):1147-55.

39. Meyer V, Wu B, Ram AFJ. Aspergillus as a multi-purpose cell factory: current status and perspectives. Biotech Lett. 2011;33(3):469-76.

40. Diaz-Fernandez D, Lozano-Martinez P, Buey RM, Revuelta JL, Jimenez A. Utilization of xylose by engineered strains of Ashbya gossypii for the production of microbial oils. Biotechnol Biofuels. 2017;10:3.

41. Young E, Lee SM, Alper H. Optimizing pentose utilization in yeast: the need for novel tools and approaches. Biotechnol Biofuels. 2010;3:24.

42. Zhang GC, Liu JJ, Kong II, Kwak S, Jin YS. Combining C6 and C5 sugar metabolism for enhancing microbial bioconversion. Curr Opin Chem Biol. 2015;29:49-57.

43. Klein-Marcuschamer D, Blanch HW. Renewable fuels from biomass: technical hurdles and economic assessment of biological routes. AIChE J. 2015;61(9):2689-701.

44. Kuhad RC, Deswal D, Sharma S, Bhattacharya A, Jain KK, Kaur A, et al. Revisiting cellulase production and redefining current strategies based on major challenges. Renew Sustain Energy Rev. 2016;55:249-72.

45. Rana V, Eckard AD, Teller P, Ahring BK. On-site enzymes produced from Trichoderma reesei RUT-C30 and Aspergillus saccharolyticus for hydrolysis of wet exploded corn stover and loblolly pine. Bioresour Technol. 2014;154:282-9.

46. van Rijn R, Nieves IU, Shanmugam KT, Ingram LO, Vermerris W. Technoeconomic evaluation of cellulosic ethanol production based on pilot biorefinery data: a case study of sweet sorghum bagasse processed via L+SSCF. BioEnergy Res. 2018;11(2):414-25.

47. Kiesenhofer DP, Mach RL, Mach-Aigner AR. Influence of cis element arrangement on promoter strength in Trichoderma reesei. Appl Environ Microbiol. 2018:84(1):e01742.

48. Merivuori H, Siegler KM, Sands JA, Montenecourt BS. Regulation of cellulase biosynthesis and secretion in fungi. Biochem Soc Trans. 1985;13(2):411-4.

49. Tomme P, Warren RA, Gilkes NR. Cellulose hydrolysis by bacteria and fungi. Adv Microb Physiol. 1995;37:1-81.

50. Kunitake E, Hagiwara D, Miyamoto K, Kanamaru K, Kimura M, Kobayashi T. Regulation of genes encoding cellulolytic enzymes by Pal-PacC signaling in Aspergillus nidulans. Appl Microbiol Biotechnol. 2016;100(8):3621-35.

51. Lockington RA, Rodbourn L, Barnett S, Carter CJ, Kelly JM. Regulation by carbon and nitrogen sources of a family of cellulases in Aspergillus nidulans. Fungal Genet Biol. 2002:37(2):190-6.

52. Suto M, Tomita F. Induction and catabolite repression mechanisms of cellulase in fungi. J Biosci Bioeng. 2001;92(4):305-11.

53. Amore A, Giacobbe S, Faraco V. Regulation of cellulase and hemicellulase gene expression in fungi. Curr Genomics. 2013;14(4):230-49. 
54. Oka H, Kojima T, Ihara K, Kobayashi T, Nakano H. Comprehensive investigation of the gene expression system regulated by an Aspergillus oryzae transcription factor XInR using integrated mining of gSELEX-Seq and microarray data. BMC Genomics. 2019;20(1):16.

55. Raulo R, Kokolski M, Archer DB. The roles of the zinc finger transcription factors XInR, ClrA and ClrB in the breakdown of lignocellulose by Aspergillus niger. AMB Express. 2016;6(1):5

56. Huberman LB, Liu J, Qin L, Glass NL. Regulation of the lignocellulolytic response in filamentous fungi. Fungal Biol Rev. 2016;30(3):101-11

57. Gielkens MM, Dekkers E, Visser J, de Graaff LH. Two cellobiohydrolaseencoding genes from Aspergillus niger require D-xylose and the xylanolytic transcriptional activator XInR for their expression. Appl Environ Microbiol. 1999;65(10):4340-5.

58. van Peij NN, Gielkens MM, de Vries RP, Visser J, de Graaff LH. The transcriptional activator XInR regulates both xylanolytic and endoglucanase gene expression in Aspergillus niger. Appl Environ Microbiol. 1998;64(10):3615-9.

59. Clutterbuck AJ. Sexual and parasexual genetics of Aspergillus species. Biotechnology. 1992;23:3-18.

60. Schulein M. Enzymatic properties of cellulases from Humicola insolens. J Biotechnol. 1997;57(1-3):71-81.

61. Sluiter A, Hames B, Ruiz R, Scarlata C, Sluiter J, Templeton D, et al. v. National Renewable Energy Laboratory. 2008 (NREL/TP-510-42618).

62. Gasser E, Ballmann P, Droge S, Bohn J, Konig H. Microbial production of biopolymers from the renewable resource wheat straw. J Appl Microbiol. 2014;117(4):1035-44.

63. Pontecorvo G. Genetic analysis of "somatic" cells in filamentous fungi. Wistar Instit Symp Monogr. 1969;9:1-8.

64. Pontecorvo G, Roper JA, Hemmons LM, Macdonald KD, Bufton AW. The genetics of Aspergillus nidulans. Adv Genet. 1953;5:141-238.

65. Cerqueira GC, Arnaud MB, Inglis DO, Skrzypek MS, Binkley G, Simison $M$, et al. The Aspergillus Genome Database: multispecies curation and incorporation of RNA-Seq data to improve structural gene annotations. Nucleic Acids Res. 2014;42(Database issue):D705-10.

66. Gibson DG. Enzymatic assembly of overlapping DNA fragments. Methods Enzymol. 2011;498:349-61.

67. Gibson DG. Programming biological operating systems: genome design, assembly and activation. Nat Methods. 2014;11(5):521-6.

68. Bradford MM. A rapid and sensitive method for the quantitation of microgram quantities of protein utilizing the principle of protein-dye binding. Anal Biochem. 1976;72(1-2):248-54.

69. Marshall T, Williams KM. Coomassie blue protein dye-binding assays measure formation of an insoluble protein-dye complex. Anal Biochem. 1992;204(1):107-9.

70. Shapiro AL, Vinuela E, Maizel JV Jr. Molecular weight estimation of polypeptide chains by electrophoresis in SDS-polyacrylamide gels. Biochem Biophys Res Commun. 1967;28(5):815-20.
71. Shevchenko A, Wilm M, Vorm O, Mann M. Mass spectrometric sequencing of proteins silver-stained polyacrylamide gels. Anal Chem. 1996;68(5):850-8.

72. Summer JB, Graham VA. Dinitrosalicylic aid: a reagent for the estimation of sugar in normal and diabetic urine. J Biol Chem. 1921;47:5-9.

73. Miller GL. Use of dintirosalicilic acid reagent for determination of reducing sugar. Anal Chem. 1959;31:426-8.

74. Singleton VL, Rossi JA. Colorimetry of total phenolics with phosphomolybdic-phosphotungstic acid reagents. Am J Enol Vitic. 1965;16(3):144-58.

75. He J, Chen D, Yu B, Zhang K. Optimization of the Trichoderma reesei endo1,4-beta-xylanase production by recombinant Pichia pastoris. Biochem Eng J. 2010;52(1):1-6.

76. Maitan-Alfenas GP, Oliveira MB, Nagem RA, de Vries RP, Guimaraes VM. Characterization and biotechnological application of recombinant xylanases from Aspergillus nidulans. Int J Biol Macromol. 2016;91:60-7.

77. Basit A, Liu J, Miao T, Zheng F, Rahim K, Lou H, et al. Characterization of two endo-beta-1, 4-xylanases from Myceliophthora thermophila and their saccharification efficiencies, synergistic with commercial cellulase. Front Microbiol. 2018;9:233.

78. Squina FM, Mort AJ, Decker SR, Prade RA. Xylan decomposition by Aspergillus clavatus endo-xylanase. Protein Expr Purif. 2009;68(1):65-71.

79. Wang J, Kang L, Liu Z, Yuan S. Gene cloning, heterologous expression and characterization of a Coprinopsis cinerea endo-beta-1,3(4)-glucanase. Fungal Biol. 2017;121(1):61-8.

80. Jain KK, Kumar S, Bhardwaj KN, Kuhad RC. Functional expression of a thermostable endoglucanase from Thermoascus aurantiacus RCKK in Pichia pastoris X-33 and its characterization. Mol Biotechnol. 2018;60(10):736-48.

81. Segato F, Dias B, Berto GL, de Oliveira DM, De Souza FHM, Citadini AP, et al. Cloning, heterologous expression and biochemical characterization of a non-specific endoglucanase family 12 from Aspergillus terreus $\mathrm{NIH2624.} \mathrm{Biochim} \mathrm{Biophys} \mathrm{Acta} \mathrm{Proteins} \mathrm{Proteom.} \mathrm{2017;1865(4):395-403.}$

82. Zhao J, Guo C, Tian C, Ma Y. Heterologous expression and characterization of a GH3 beta-glucosidase from thermophilic fungi Myceliophthora thermophila in Pichia pastoris. Appl Biochem Biotechnol. 2015;177(2):511-27.

83. Yan Q, Hua C, Yang S, Li Y, Jiang Z. High level expression of extracellular secretion of a beta-glucosidase gene (PtBglu3) from Paecilomyces thermophila in Pichia pastoris. Protein Expr Purif. 2012;84(1):64-72.

84. Yang S, Hua C, Yan Q, Li Y, Jiang Z. Biochemical properties of a novel glycoside hydrolase family 1 beta-glucosidase (PtBglu1) from Paecilomyces thermophila expressed in Pichia pastoris. Carbohydr Polym. 2013;92(1):784-91.

\section{Publisher's Note}

Springer Nature remains neutral with regard to jurisdictional claims in published maps and institutional affiliations.
Ready to submit your research? Choose BMC and benefit from:

- fast, convenient online submission

- thorough peer review by experienced researchers in your field

- rapid publication on acceptance

- support for research data, including large and complex data types

- gold Open Access which fosters wider collaboration and increased citations

- maximum visibility for your research: over $100 \mathrm{M}$ website views per year

At BMC, research is always in progress.

Learn more biomedcentral.com/submissions 